\title{
The Private and the Public in the Republic and in the Analects ${ }^{1}$
}

\section{Introduction}

Plato's Republic and Confucius's Analects are two founding texts of political philosophy in the West and in China respectively. In spite of many differences, Confucius and Plato were facing a common problem: the threat of the private to the public. But they offered apparently radically different solutions. In this chapter, I will first present both models and then compare them with each other.

In Section 2, I will discuss how the Analects deals with the issue of the private and the public. The Analects consists of apparently scattered and brief conversations. To tease out hidden messages in the Analects, I will also use many passages from the Mencius, another important early Confucian text, with the assumption that these passages are consistent with and can be considered an elaboration of the related themes in the Analects. Given the limited space, I cannot justify this assumption, and have to take it for granted. So, 'the Analects' used in this chapter is a symbol that represents certain strands of early Confucian thought, especially that found in the Analects and in the Mencius. With this caveat I will show that, although recognizing the conflict between the private and the public, the Analects pays more attention to the elements of the private that are constructive to the public, and uses the private as the natural locus of instilling people with public-mindedness. Where there still remains conflict between the private and the public in the mentioned texts, it will be resolved in a contextual manner. But I will also show, very briefly, how Han Fei Zi, the early Chinese Legal thinker, challenged the adequacy of Confucian solutions.

If Confucian solutions are indeed inadequate, we may have to search for another model. This leads us to the discussion of the model put forth in the Republic. In Section 3, I will show that the Republic understands the private mostly as a threat to the public, and tries to suppress it nearly completely in order to protect the public. But this proposal also faces some fundamental challenges, which early Confucians would have, and Aristotle actually did make.

1 The research for this chapter was supported by the Program for Professor of Special Appointment (Eastern Scholar, second term) at Shanghai Institutions of Higher Learning, I also wish to thank the organizers of the Turin conference on Cicero and Confucius, and in particular, Prof. Andrea Balbo, for including me in this interesting project.

2 OpenAccess. (C) 2019 Tongdong Bai, published by De Gruyter. (cc) BY-NC-ND This work is licensed under the Creative Commons Attribution-NonCommercial-NoDerivatives 4.0 License. https://doi.org/10.1515/9783110616804-003 
In the last section, I will offer some further reflections. First, I will show that the contrast between the two models is not between China/East and West. Rather, these models offer paradigms for us to reflect on the history of political thought and on some fundamental issues in politics and political philosophy. As examples, I will show how these two models can be compared with certain mainstream modern understandings of the relations between the private and the public and teachings based on these understandings. I will also reflect on the issue of how to solve the conflict between the private and the public in light of the apparent failures of these two models.

There are already numerous works dedicated to the study of these texts, and of the issue of the relationship between the private and the public. I will focus on a textual analysis of these two texts without diving into these studies that I choose not to cite, and this would not, to my knowledge, affect significantly the results and methods of this study. The contribution I wish to make in this chapter is limited: to put these two texts side by side, to show an intriguing contrast between them, and to discuss some implications of this contrast. By showing the 'commensurability' between these texts, I wish to pave the way for promising mutual engagements between the two great philosophical texts, and between the Confucian and the Platonic traditions, as well as their implications to the history of political philosophy and to certain problems in political philosophy and in political matters.

Before going into these texts, I will first offer some general discussions of the two key concepts in this chapter: the private and the public. ${ }^{2}$ It should be first made clear that these two concepts are relative. The private is what is one's own, and the public is what is beyond one's own. But 'one's own' has some indeterminacy. If we take the interest of one person as private, the interest of his or her family or extended family can be taken as a form of public interest. But with regard to the interest of a community that is not merely based on kinship, (one's own) family's interest should be regarded as private interest. Again, the interest of one's own community can be considered private with regard to the interest of a collection of communities or the interest of the state. However, it seems that it takes little effort, perhaps no effort at all, for human beings to be self-interested ('self' here means the individual person), and, for the majority of people, it takes a little more effort, but is still quite natural ('natural' in the sense of 'effortless') through either natural affinity to or the nurturing and supportive environment of

2 I wish to thank Loy Hui-chieh for encouraging me to clarify these concepts, and Hao Changchi 郝长墀 and especially Zhou Xuanyi 周玄毅 for helping me to see the relative nature of these concepts. 
one's own family - to develop a concern with the interest of the family. Thus, although what is private is relative, one's own self-interest and one's own family's interest are often the primary sources of private interests, in spite of the relative nature of what is taken as private interest. However, we should also see that the interest in the family, including holding the interest of other family members above that of one's self, is the first step for a person to go beyond the narrow interest of the individual self and to be concerned with others. The double features of one's family interest, often 'naturally' (effortlessly) considered one's own (private) on the one hand, and being the first step to go beyond the private in its narrowest and most natural (most effortless) sense on the other, will play a significant role in the Confucian treatment of private-public relations. It should also be noted that one person's self-interest is not necessarily the same as his or her material interest. Indeed, both the Republic and the Analects argue that one's material interest should be subjected to the rule by some higher good. In the $R e$ public, this idea is expressed through the belief that an ordered soul is just (434d445e; c.f. 351b-352c) and the idea that even this 'just' soul (which is actually only partially just) can only be beneficial and useful when it is guided by the Good (504a-506b). ${ }^{3}$ In the Analects, the hierarchy within what is considered an individual person's own is expressed through putting what is right ( $y i$ 义) above what is materially profitable (li 利): see, for example, 4.16 of the Analects. ${ }^{4}$ With these two key concepts clarified, now let us first take a look at how the Analects deals with the private-public problem.

\section{How to solve the conflict between the private and the public: the model in the Analects}

During the Spring and Autumn and Warring States periods in Chinese history (SAWS for short, lasting roughly from 770 B.C.E. to 221 B.C.E.), when the early Confucians lived, the unity of the Zhou dynasty was increasingly challenged by the growing powers of its vassal states; the unity of each vassal state was more and more challenged by the growing powers of its powerful noble families; and the unity of each clan was more and more threatened by ambitious lesser lords. It was an age of political factions, and it was a jungle in which everyone

3 The translation of the Republic I am using in this chapter is Bloom (1991).

4 For an English translation of various passages of the Analects mentioned in this chapter, see the corresponding parts of Lau (2000). The translations of the Analects in this chapter are all mine. 
and every entity fought for his or its own survival and dominance, oftentimes by all means possible.

Underneath all the chaos is the conflict between the private and the public. Seeing it having gone wild on every level, early Confucians also saw the constructive aspect of the private, which could lead to harmonization of the conflict between the private and the public. As Confucius said in the Analects, "the way of practicing ren [benevolence or humaneness, a kind of public-spiritedness] is to find analogy from what is near at hand" (6.30). This means that what is near, or the private, is crucial for what is 'far,' or the public. In particular, for Mencius, to have stable possessions (property) is important for a member of the masses to have stable character (virtues) (1 A7 and 3 A3 of the Mencius). ${ }^{5}$ Moreover, in an encounter (1B5), a king confessed to Mencius that he had two weaknesses: he was fond of women and of money. But Mencius said that two humane rulers in the past had similar desires. But precisely because of these, they understood that their people must have had similar desires, which led them to make sure that, in the case of the ruler who was fond of women, there were "neither girls pining for a husband nor men without a wife" under his rule. What is implied in this passage is that, without the king's own fondness of women - a private interest, he would not have been able to understand the interest of his people or the public interest. ${ }^{6}$

But it is crucial that we not only understand others' needs, but also are motivated to satisfy them. The latter needs to be cultivated, and the best place for this cultivation, according to early Confucians, is within the family. As mentioned before, family plays the dual role of being both private (with regard to a larger community) and public (with regard to one's individual self). Love among family members can then play the role of expanding one's private interests to the public realm. You Zi (有子), someone considered almost an equal to Confucius, claimed in the Analects,

Exemplary persons concentrate their efforts on the root, for the root having taken hold, the way will grow therefrom. As for filial and fraternal responsibility, it is ... the root of humaneness. (1.2)

5 For an English translation of various passages of the Mencius mentioned in this chapter, see the corresponding parts of Lau (2003). The translations in this chapter are all mine.

6 This understanding poses an interesting contrast to an example of the moral man Kant offered. This man is someone who by nature lacks sympathy and is cold and indifferent to the sufferings of others, and, indeed, his coldness and indifference is crucial for his philanthropic act to others to be considered moral: Kant (1998) 11; 4:398. 
Throughout the Confucian tradition, the analogy between father-son relations and ruler-subject relations is prevalent (see, for example, 12.11 of the Analects). The state is not an enlarged individual, as Socrates suggested in the Republic (368c-369b). Rather, the state is an enlarged family. The devotion to the enlarged family is developed from the devotion to the natural family. As Mencius put it,

Treat the elderly of my own family [as they should be], and extend this treatment to the elderly of other families; treat the young of my own family [as they should be], and extend this to the young of other families... Thus extending one's humaneness outward can protect everyone within the Four Seas [the alleged boundaries of the world], and not extending one's humanity cannot even protect one's wife and children. (1 A7 of the Mencius)

Indeed, what Mencius suggested here is that through the expansion of care, eventually, one will embrace everyone in the world.

For early Confucians, however, those who can achieve this universal care are few in number. Even if it is achieved, the universal care will have to be hierarchical, and justifiably so. This is the Confucian idea of graded love (爱有差等). Mencius made a good illustration of this. He said,

an exemplary person is [...] holding his parents dear (qin亲) but is [merely] humane toward the people; he is humane towards the people but is [merely] sparing with things [or not wasting things; 爱]. (7 A45).

As indicated by the root metaphor in 1.2 of the Analects, our care for our fellow human beings is rooted in our care for our family members. The root has to be strong enough to hold the whole tree. Otherwise, it would be blown over easily.

For example, if I have only one loaf of bread, which is only enough to save one starving person, naturally and justifiably, I will use it to save a close family member rather than a stranger, even if I am a person of universal goodwill. ${ }^{7}$ Does this mean that we always put our family duties first? Confucius 'seems' to think this way. In a passage in the Analects, a governor boasted to Confucius that the upright person in his village was someone who bore witness against his father who stole a sheep. Confucius replied by saying that the upright people in his (ideal) village behaved differently in that a father covered up for his son, and a son covered up for his father (13.18). But this passage should not be read as Confucius's always taking family interest as supreme. For, first, stealing a sheep is a petty crime. Second, the hidden rationale for Confucius's claim may have been that, if the son turned the father in, the father would lose trust in

7 A later Confucian Wang Yangming (王阳明 1472-1528) made exactly this point: Wang (1992) 108. 
everyone in the world because his closest kin betrayed him. In the future, he may be law-abiding, but this will not be because he thinks that it is the right thing to do, but because of the fear of punishment. As Confucius put it in another passage, if we only used laws, people would be law-abiding but shameless (2.3 of the Analects). A society of shameless people is dangerous! Third, to conceal the father's misconduct does not mean letting him go free. Rather, by concealing a family member's misconduct, thus preserving the loving relationship and trust, one can more effectively help this person to right wrongs.

Therefore, with the premise that the public-spirit should be rooted in family care, Confucius tried to solve the conflict between the private and the public not by negating the private completely, and not by laws alone, which, as we will see, poses a sharp contrast to the treatment of the conflict in the Republic. Instead, Confucius tried to offer a contextual solution that addresses both private and public duties at the same time.

One problem with the aforementioned case, however, is that the crime involved was a petty one. What happens if the father committed a murder? Confucius didn't deal with this kind of case in the Analects, but Mencius did. In 7 A35, he is asked about a hypothetical case. In this case, the father of the sage ruler Shun's murdered someone, and Mencius was asked what Shun should do. Mencius suggested that, on the one hand, Shun should not stop the police chief from trying to arrest his father, in spite of the fact that Shun, as the ruler of tian xia (the world, as it was known to the Chinese), had legitimate authority to pardon his father; on the other, he should give up his throne and run to a remote place with his father as a fugitive. Again, based on the continuity picture between the private and the public, Mencius tried to strike a balance between two conflicting duties.

To sum up, for early Confucians, the opportunity to overcome the threat of the private to the public comes from the private as well. The constructive part of the private should be cultivated to serve the public. When there are still conflicts of duties, the solutions need to be found in a contextual manner. There is no predetermined 'field manual', and cases in the early Confucian texts should be taken as inspiring examples to help us to think through the conflicts in our lives.

But a challenge still remains: can all conflicts be resolved? In the hypothetical case in the Mencius, what about the victim's family? What about the people the sage ruler Shun left behind? Shouldn't he be concerned with how they would live without his moral leadership? Han Fei Zi, a so-called Legalist thinker in the Warring States era who allegedly studied with another important early Confucian thinker, Xun Zi, and who thus might have known Confucianism well, raised his own powerful objections. To the Confucian point that laws, if they are used, should be based on a morality that begins with the family, he argued that the 
cultivation of family care may come into conflict with what the public or the laws require. The Confucian can respond by saying that this conflict can be solved in a contextual manner. To this, Han Fei Zi has two counter-arguments. First, sometimes, the conflict is too deep to be resolved. Second, the contextual and sophisticated treatments offered by Confucius and Mencius are beyond the capacities of the masses, while to regulate them effectively should be the main goal of a successful regime. In particular, a state that is well-run should rely on laws and rules, because even the masses can understand them well. ${ }^{8}$

Han Fei Zi offered a few cases in which he wished to show that the conflicts between the private and the public are irresolvable, but it can be argued that there are Confucian solutions to these dilemmas. A challenging case I have discovered comes from Shi Ji (史记, Records of the Grand Historian), in which Sima Qian (司马迁) described the following historical case: ${ }^{9}$ Shi She (石奢), a minister of Chu (楚), hunted a murderer down, only to find that the murderer was his father. Letting his father go, he turned himself in and asked the king to punish him with death penalty. The king forgave him. But Shi She argued that arresting his father would not have been the filial thing to do, but that it was also not loyal to disobey the King's law. Although it was up to the king's discretion and leniency to forgive him, it was his duty to pay for his crime. Then, he committed suicide. I doubt that a Confucian can offer a better solution than this. But this solution is an acknowledgement of the lack of harmonious solution to this kind of conflict. In this situation, the continuity between the private and the public breaks down, and the conflict cannot be overcome in a constructive manner. The Confucian continuity and harmony model fails in such extreme cases.

\section{How to solve the conflict between the private and the public: the model in the Republic.}

As we have seen, the two key challenges to the early Confucian model are about the effectiveness of morality-based contextual solutions and about whether the conflicts between the private and the public spheres can always be harmonized. As far as the problem of the conflict between the private and the public is concerned, the approach in Plato's Republic seems to consist in a total suppression of the private and an emphasize on establishing laws rather than cultivating

8 He made these arguments throughout the Han Fei Zi. In particular, please refer to Chapter 49 of this book. For an English translation, see Watson (1964).

9 Sima (1986) 339. 
family-based morals. In this section, let us focus on whether this approach works better than the Confucian one.

Although Plato's Athens and the city (polis) discussed in the Republic are different from the relatively large and populous states extant during the SAWS periods in China, both environments shared the problem of having to deal with factions, or the conflicts of different interest groups. In Plato's Athens, factions were often family- or clan-based. If we take the common good of the city as constituting the public, the interest of the family and the clan (as as well as the interest of an individual person) should then be considered private. So, the problem of factions is a problem of the conflict between the private and the public.

In sharp contrast to the model in the Analects, however, the aspects of private interests and family matters that are commonly regarded as benign and even beneficial to the public are largely ignored in the Republic. A telling example is that, when discussing what laws to establish in the ideal city, Socrates ${ }^{10}$ lists a few things as small and secondary conventions, for which no laws need to be established. Among these are appropriate conduct in treating the elders and the care of parents (which are taken as the root of Confucian morality by early Confucians); these are listed next to what are considered proper hair-dos (425a-c).

In contrast, Socrates pays far more attention to the clear distinction and conflict between the private and the public. For example, at one place, Socrates states that a private man cannot lie to the rulers, although it is appropriate for the rulers to lie for the benefit of the city (389b-c). Commenting on this, Allan Bloom - a well-known contemporary translator and a commentator of the $R e$ public - points out that the "opposition between the private and public is an important theme in the Republic and, in some respects, it is the core of the problem of justice". ${ }^{11}$

Given this sharp distinction, much of the Republic is then focused on how to suppress the private. In particular, almost anything private is forbidden to the two ruling classes (philosophers-kings, guardians and their auxiliaries). For example, in Socrates's discussion of the material conditions of the lives of the guardians (415d-417b), guardians are not allowed to have any private property. There is not even a private space, such as a house or a storeroom, for the guardians (416d). The reason for abolishing these things is that the private possessions will turn the guardians into "masters and enemies instead of allies of the other

10 In this chapter, by 'Socrates', I mean the character in the Republic, a 'play' created by Plato. Whether this Socrates is based on an accurate portrait of the historical Socrates is not relevant here.

11 Bloom (1991) 445-446, note 41. 
citizens" (417a-b). This transformation will lead to factional conflicts, and eventually the destruction of the city. Instead, the city has to provide the guardians with sufficient sustenance and other necessities of living (but with no surplus). The guardians live and eat together, and this communal life is clearly intended to nourish the camaraderie among them.

Nevertheless, although their self-interest ('self-interest' in the narrow sense of this word, i.e., as separate from the family interest) is largely suppressed, the guardians may still form factions based on their family ties because, as we see in the discussion of the concepts of private and public in the first section, family interest is the other primary source of private interest. This is a reason why Socrates later proposes to abolish families altogether (457c-471b). Through some complicated, almost impossible, arrangements, only the best men - "the young who are good in war or elsewhere" (460b) - and the best women are allowed to reproduce. The newborns are immediately taken away from their mothers, any possible identification of them with their birth mothers being thereby eliminated. These babies are to be raised by the city. As a result, the male and female guardians have to treat all citizens of the city as blood relations, and cannot favor some over the others on the basis of family ties. As Bloom put it, "To become either a member of a city - or a philosopher - one must break with one's primary loyalty". ${ }^{12}$

These arrangements also help to solve another crucial problem in politics: how to make rulers care for the city and the citizens. At two separate places, Socrates offers two good reasons for good men or philosophers to rule: to avoid the penalty of being ruled by a bad ruler (347a-d), and to pay back what is owed to the city (520a-b). One problem that is relevant to our discussion is that neither reason sufficiently motivates the good people to rule. In contrast, in the Confucian model, the rulers should be those who succeed at Confucian moral cultivation. That is, they should be the ones who are motivated to care for the wellbeing of the people.

Perhaps aware of this, Socrates introduces means to strengthen the motivations of potential rulers. Socrates argues that the guardians have to be selected on the basis that, not only do they have the knowledge of how to guard the city, but they have the firm conviction that what is advantageous to the city (public) is also advantageous to themselves (private). Only those who can hold onto this belief against all sorts of tests will be chosen as guardians (412b-414b). It seems, however, that Socrates does not think that mere education is sufficient to instill public-spiritedness in the guardians; rather, a noble lie has to be told to all citi-

12 Bloom (1991) 385. 
zens (414b-415d). They are told that they were born from the land of their city and made of different metals. As a result, the land is their mother, and they are all brothers to each other. With this belief, the rulers will love the land of the city - in a literal sense - as their mother and the citizens as their brothers. The aforementioned proposal of the abolishment of family can be taken as a further reinforcement of the noble lie. That is, through abolishing family altogether and adopting a community of women and children, any citizen the guardian meets is "a brother, or a sister, or a father, or a mother, or a son, or a daughter or their descendents or ancestors" (463c). ${ }^{13}$

To be clear, not all private interests are suppressed. ${ }^{14}$ As pointed out, the city offers sustenance to the ruling class, thus satisfying some of its private interests. But this satisfaction is so basic that these guardians and their auxiliaries are not happy, like poorly-paid mercenaries (419a-420a). Of course, a particular private interest, their sense of honor, is indeed adequately satisfied (413e-414a and 468b-469b). Moreover, it can be argued that the producer class (the masses that are ruled) also has some private interests satisfied. It is possible that they can have private property and families, and their way of life is protected by the ruling class. But the Republic never makes this explicit, and we can imply from some passages that even this limited satisfaction of their private interests can be violated. For, after all, as Socrates argues (in his answer to the complaint that guardians are not happy), the happiness of the city as a whole should be our only concern, and this suggests that, if the private interests of the masses have to be suppressed for the greater good, or for the Good (which, in the Republic, is not defined as the sum of the private interests of all citizens, as both Confucians and we moderns often understand it), we can suppress them. Thus, as pointed out earlier, the private interests that are not harmful to the common good or are too difficult to exterminate (unless, for example, we can take away the body which is actually considered in the Phaedo 61b-65b; see also 172c-177c of the Theaetetus) are not suppressed and are (often meagerly) satisfied, but the Republic pays little attention to them. In contrast, the focus is on how private interests that are in conflict with the public good can be suppressed. With these interests completely suppressed, the public interest is not threatened anymore. Unity, the

13 It is debatable how effective Socrates actually thinks all these arrangements are in making the good men devoted to the public interest. For example, in Book VII, the philosophers (the best men), after seeing the good, have to be compelled to serve the common people (514a-521b). 14 I wish to thank Liu Wei (刘玮) for encouraging me to make this clarification, and I have benefitted from the discussions with him in some of the points that will be made in the following. 
'allegedly'15 greatest good of the city, is achieved, with the help of maintaining a proper size of city (423b-c and 461e-466c). All its citizens, especially those of the ruling class, will have a shared sense of pain and pleasure among themselves, "like a single man" (462c). There are no factions among the citizens, and the conflict between the private and the public is solved by the total annihilation of the private interests that are in conflict with the public interest. However, it should be pointed out that Socrates thinks that the aforementioned arrangements - especially the abolishment of the family - are unlikely to be carried out in real life, unless philosophers become kings or kings happen to be philosophers, a very rare event, if it is possible at all (471c-474c).

As I mentioned at the beginning of this section, by almost completely suppressing private interest, and by focusing on laws, the model in the Republic seems to be able to get around the challenges to the early Confucian model. But a defender of the early Confucian model would argue that, if family is completely abolished, where do citizens get a sense of family bond? A key problem here is that, on the surface, in the Republic, much of the private is abolished for the sake of the public, but by making the city a big family, Socrates secretly wishes to take advantage of the beneficial aspects of the private sphere. Unfortunately, one cannot have one's cake and eat it too. The guardian is deprived of any connection with the family, and nowhere in the Republic is the education of filial love and compassion seriously promoted. This invalidates the demand that the guardian love his or her country as motherland and its citizens as brothers and sisters (i.e., family). Without family, 'father and mother' and 'brothers and sisters' carry no significance, and they only gain significance when filial affection for family members is cultivated in a family environment. Or, using the metaphor in 1.2 of the Analects, the big family in the Republic is like a rootless tree. One may argue that guardians can gain a sense of camaraderie through community. ${ }^{16}$ But a Confucian can argue that the close ties that are necessary for camaraderie would secretly reintroduce de facto family relations back into society and thus lead to conflict between the private and public spheres about which Socrates is worried; or the ties would not be so close, making the alleged camaraderie too diluted to be meaningful.

In contrast, according to the Analects, the natural love among family members, present in a family environment can achieve what the artificial noble lie and the practically impossible arrangements of community of women and chil-

15 The reason to claim that unity is allegedly the greatest good is that Socrates later claims that the Good is the highest good (504d-505b), and it is questionable whether unity is always part of the Good. A reasonable guess is that unity, like justice, is only good by its relation to the Good. 16 I wish to thank Tao Lin (陶林) for making this point to me. 
dren in the Republic try to achieve. Anecdotal support for the viability of the Confucian model is that, although Socrates dreams of a world in which people call strangers with names usually reserved for family members, this practice of, for example, calling a stranger of a similar age 'brother...' or 'sister...' is an actual practice in China, probably thanks to the Confucian heritage. ${ }^{17}$

Interestingly, Aristotle actually offered Confucianism-style criticisms of the Republic. ${ }^{18}$ In his Politics, the relationship between husband and wife in a family is described in political terms, which resonate more with the Confucian familystate analogy than the soul-state analogy in the Republic, although he also emphasizes the fact that there are differences between "a large household and a small city" (1252a1-1252b35). In his criticism of the Republic, he implies that the private and the familial spheres are important loci for the education of public virtues. For example, Aristotle argued that, without private property, one would not be able to learn generosity and affection for "friends, guests, or club mates" by overcoming one's self-love and using one's own possessions to help out (1262b1-6). This resonates partly with Mencius's claim that property is crucial for people to have virtues. Aristotle also argues that, without the family setting, one cannot learn proper respect for family members and, eventually, appropriate attitude toward strangers (1262a25-33). Generally, Aristotle is known for emphasizing education toward virtue through habituation, and family and the "private sphere' are a natural setting for this (1263b40). Like the Confucians, he also believed that, by treating all citizens as family members and distributing affection to all of them, "affection necessarily becomes diluted through this sort of partnership," and without what is one's own and what is dear, human beings would not be able to cherish and feel affection (1256b6-35).

One might argue that the political proposal on the surface of the Republic is too 'crazy' to be taken literally, realistically, and seriously. My reason for focusing on this model is that it poses an interesting contrast to the one offered by early Confucians, and to take what is apparently proposed in the Republic seriously does not deny the possibility of hidden teachings residing in the Republic. To understand the hidden, however, we need to understand the surface first. Moreover, it cannot be denied that the surface proposal offered in the Republic has been taken literally and seriously throughout history, and it is a paradigm that nicely represents many political ideas in history. The conflict model discussed in this

17 Another interesting contrast is that, when we call a stranger "sister" in English, it often means that this stranger is a nun. In other words, the idea that all human beings belong to an extended family in the West may come from Christianity (or, looking at this from the opposite perspective, we can say that family, not God, is the Confucian path to transcendence).

18 I wish to thank the late Robert Rethy for some very helpful discussion on this point. 
chapter was a (significantly) revised version of the real-world Spartan regime, and has inspired various forms of totalitarianism and utopianism in history (or at least it represents their underlying ideas). It is criticized by philosophers such as Popper (1971) due to its connection with totalitarianism and utopianism. Of course, Popper's understanding of the Republic may have been rather limited, but as we just saw, even Aristotle - the great, but perhaps not so faithful pupil of Plato's - also took the surface proposal seriously (and critically). All of this justifies a literal reading of the conflict model in the Republic.

\section{Further remarks}

After presenting these two contrasting models and letting them 'criticize' each other, let me make a few more comments. The comparisons between these two models are clearly not fundamental comparisons between East/China and West. As we have seen, it was Han Fei Zi, a Chinese political thinker, who challenged the Confucian view of harmony, and it was Aristotle, a Western thinker, who criticized the Republic for its neglect of the constructive aspect of the private. Rather, the sharp contrasts between these two models help us to see the merits and demerits of each model in light of the other, and these two models are useful paradigms for us to use in thinking about the issue of the private and the public in both the history of political thought and in real-world politics, past and present.

For example, due to the break between the private and the public, it becomes possible, in the picture offered in the Republic, that a city as a whole may be happy without any of its members being happy (419a-421c), or that the Good be detached from the good of any individual. This understanding resonates with the understanding of the public good in certain versions of totalitarian regimes.

Paradoxically, however, the belief in this sharp break between the private and the public is shared by a version of modern liberalism, the one with the motto that what happens in one's bedroom is not the business of the state. What differentiates them is whether one wishes to protect the public against the private (the Republic) or the private against the public (liberalism).

Against this background, the early Confucian model possesses a curious place. It stands with the Republic in its concern with the threat posed to the public by the private. But it stands with more liberal democratic ideas in that the public interest is the sum of the interest of the people. For example, Jeremy Bentham claimed that the utility of a whole community is nothing but the sum of the utility of all its members (Bentham 1948-1789, 1-3). Indeed, Confucians may 
have been those who first introduced this 'modern' idea, ${ }^{19}$ but they might not have agreed with the contemporary understanding of it. First, for the Confucians, the sum of interest is not the same as the sum of mere material interest. Second, the sum of interest is not a simple accumulation of individuals' interests. There can be interests that only emerge in a group, such as those based on family or communal relations.

Moreover, as we saw, early Confucians rejected the sharp divide between the private and the public. If this is the case, what happens in one's bedroom can affect and even harm public interests. This could be a challenge to the typical liberal lack of concern for virtues (with the assumption that many of the virtues belong to the private sphere). Indeed, in spite of the separation between the private and the public, the Republic also suggests that what happens in private can be harmful to the public, which is why it calls on an almost total suppression of the private.

Let me end my reflections with a few words on the key issue in this chapter: which model can better deal with the conflict between the private and the public? To address the problems of the conflicts between the private and the public, a key challenge to the Confucian model, the model in the Republic suppresses the private completely. Using the root metaphor, the Confucian 'tree' is well-rooted, but it cannot resist extremely strong winds. The 'tree' in the Republic is designed to resist the strongest wind, but it turns out to be an illusion because the strong-looking tree has no root. One can argue that some mixed model may be superior, but how to mix these contrasting models poses a significant challenge. Perhaps this suggests that some fundamental conflicts in human life cannot be solved adequately in politics. Or, to put it in a colloquial or even vulgar manner, 'life sucks'.

19 Fleischacker (2004) 2 and 53-79 argues that the idea of government having a duty to satisfy everyone's basic needs was only introduced to the West in the $18^{\text {th }}$ century, whereas it was introduced by Confucians much earlier: Perry (2008) 39. 